\title{
Protection against Domestic Violence in Jordanian Law and International Conventions
}

\author{
Laith K. Nasrawin \\ Associate Professor in Public Law, School of Law, The University of Jordan, \\ Amman, Jordan \\ l.nasrawin@ju.edu.jo; laith@lawyer.com
}

\begin{abstract}
This article addresses the issue of protection against domestic violence in both Jordanian law and international conventions. It does so by defining domestic violence and its various causes and by exploring the relevant global standards and best international practices for combating it. The article also deals with the reality of protection against domestic violence in Jordan by referring to the special protection of the family and to the related follow-up by national and governmental institutions, and the relevant national standards. The Law Regarding Protection from Domestic Violence (Law No. 6/2008) contains protective provisions and other treatments to reduce this phenomenon, but it fails to provide optimal protection against domestic violence. The article proposes a set of recommendations to improve national standards for protection against domestic violence so that Jordan's laws concerning protection against domestic violence conform to international standards.
\end{abstract}

\section{Keywords}

domestic violence - domestic violence causes - Jordanian Law for Protection from Domestic Violence - international standards of domestic violence protection

Domestic violence is one of the most important obstacles to promoting and protecting human rights in the Middle East and globally, particularly given its nature and the problems that accompany it, as well as the difficulty of 
disclosure and the multiplicity of legal, social and economic causes that prevent prosecution in some cases. The phenomenon of domestic violence is not the result of time, a particular circumstance or specific cultural or civilizational, economic or political situation; it has accumulated over centuries and is the product of a shared cultural heritage that justifies the power of men over women. ${ }^{1}$

In Jordan, domestic violence is widely regarded as a family matter that affects large numbers of women, children and adults across their lifespan. In cultural and religious matters, Jordanian society has conservative attitudes towards gender roles within society, and the behaviour of men and women is strictly defined, and formed according to the social system. Indeed, a 2002 report by the United Nations Development Fund for Women found that women in Jordan who were victims of intimate partner violence were often reluctant to report the violence to police or authorities out of fear of social unacceptability and shame. ${ }^{2}$ Battered women may also be pressured by their families to drop the charges - in Jordanian culture, violence against women is considered a private and sensitive family matter. ${ }^{3}$

Very little is known about violence against women in Arab society, including Jordan, as most literature on violence against women is concentrated on Western societies. ${ }^{4}$ Regardless, national, regional and international efforts must continue to eradicate the scourge of domestic violence in all its forms and manifestations, from the basic understanding that violence cannot be justified under any circumstances. ${ }^{5}$

Since the beginning of the last century, a number of international efforts have combatted domestic violence. International conventions and declarations have been issued to oppose violence against women, ${ }^{6}$ such as the Convention on the Elimination of All Forms of Discrimination against Women (CEDAW,

1 Richard L. Davis, Domestic Violence: Facts and Fallacies (Westport, ст: Praeger, 1998), 8-9.

2 United Nations Development Fund for Women Amman, Jordan, The Status of Jordanian Women Report, wHo Report on Violence and Health (Geneva: World Health Organization, 2002).

3 N. Linos, M. Khawaja \& M. Al-Nsour, 'Women's autonomy and support for wife beating: Findings from a population-based survey in Jordan', Violence Victims 25(3) (2010): 409-419.

4 R. Btoush \& M. Haj-Yahia, 'Attitudes of Jordanian society towards violence against women', Journal of Interpersonal Violence 23(11) (2008): 1531-1554.

5 See Mohammad Olwan \& Mohammad Almousa, The International Law on Human Rights Protected Rights - Part 2 (Amman: Dar Althaqafa for Publication, 2011), 513-515.

6 Linda L. Dahlberg et al., Measuring Violence-Related Attitudes, Behaviors, and Influences Among Youths: A Compendium of Assessment Tools (Atlanta, GA: Division of Violence Prevention, 2005), 2-4. 
1979), the Declaration of the Elimination of Violence against Women (1993) and the Convention on Preventing and Combating Violence against Women and Domestic Violence (Istanbul Convention, 2014). Despite these efforts, domestic violence has continued, and increased in frequency, in most regions of the world, especially in the Middle East and North Africa, ${ }^{7}$ constituting an obstacle to the global movement for protection in general and the promotion of women's rights in particular, and an obstacle to ensuring women's optimal enjoyment of their human rights.

In Jordan, despite the progress that has been made in human rights in general and women's rights in particular, domestic violence continues to stalk the community, which appears unable to control it or diagnose the real reasons for it. Jordan has undertaken a number of procedural, administrative, judicial and legislative measures to combat and eliminate domestic violence. It has created many public welfare institutions and has given them a general mandate to provide protection programmes, promoted in all regions of the kingdom. Departments for family protection have been established at both the Public Security Directorate and the Ministry of Social Development, and a National Council for Family Affairs has also been created.

National efforts to tackle domestic violence culminated in the Law Regarding Protection from Domestic Violence (Law No. 6/2008), 8 the primary aims of which are to preserve family ties, eliminate the crime of domestic violence and reduce the consequences of criminal proceedings.

Nevertheless, the high incidence of domestic violence confirms that recent governmental efforts have failed to counter the phenomenon, which represents a flagrant violation of the right to life and physical integrity and of the right to live with dignity in Jordanian society. ${ }^{9}$ Therefore, the fight against this phenomenon should become a priority for all, and should be a shared responsibility of governments, national institutions, civil society organizations, and international and regional organizations alike.

Thus, Law No. 6/2008 is critically analysed here in order to decide whether its rules comply with international standards for protecting the rights of women against domestic violence. Jordan is a signatory to various international

7 Debbie D. Abuelghanam, 'Domestic violence services, training and funding in Jordan', Dirasat, Human and Social Sciences 41(10) (2014): 284-286.

8 See the Official Gazette No. 4892, 16 March 2008, 821.

9 The prevalence of domestic violence in Jordan shows that approximately one out of every three women will be abused during her lifetime. See C.J. Clark et al., 'Violence during pregnancy in Jordan: Its prevalence and associated risk and protective factors', Violence against Women 15(6) (2009): 3 . 
instruments for the protection of women against domestic violence, such as CEDAW, and as such, the national law in question needs to be checked against these norms and amended where necessary to ensure full compliance.

Domestic violence can be defined as a pattern of abusive behaviour, in any relationship, used by one partner to gain or maintain power and control over another. It can be physical, sexual, emotional, economic or psychological actions or threats of actions that influence another person, including any behaviour that intimidates, manipulates, humiliates, isolates, frightens, terrorizes, coerces, threatens, blames, hurts, injures or wounds someone..$^{10}$ The term 'domestic violence' was first used in studies during the 1970s to refer to acts of violence and abuse against wives. However, the concept has been expanded through the 1990s to include all acts of violence between members of one family.11

Domestic violence is the result of many factors, one of which is a family's economic conditions. Domestic violence is common in families that suffer from widespread poverty and rampant unemployment, and that are consequently less able to withstand social pressures, especially if the father is unemployed, meaning that the family lives in difficult housing conditions and lacks sources of income for its needs. ${ }^{12}$ Poverty among women also plays a major role in the spread of domestic violence - studies indicate that women are among the poorest segments of society, accounting for seventy per cent of the total poor. ${ }^{13}$

Another cause is the husband's or wife's relatives failure to intervene early. Studies suggest that most families in which domestic violence occurs lack extended family in the area, and are thus deprived of the family support necessary to meet and deal with family dilemmas. ${ }^{14}$ There are also cultural reasons, which lie in a social culture that sees cruelty and violence as methods of influence and control. The man, according to the community culture, is the boss in

10 Richard L. Davis, Domestic Violence: Intervention, Prevention, Policies, and Solutions (New York: CRC Press, 2008), 1-2.

11 Donald G. Dutton, Rethinking Domestic Violence (Vancouver: Uвс Press, 2006), 5-7.

12 Supra note 3 at $284-285$.

13 Claire M. Renzetti \& Daniel J. Curran, Women, Men and Society, 5 th ed. (New York: Pearson Education, 2003), 202.

14 Frank D. Cox, Humanity Intimacy: Marriage, the Family and Its Meanings, 1oth ed. (Belmont, CA: Thomson Wadsworth, 2006), 447-450. 
the family, and is not expected to pay attention to his wife's point of view, or even to that of his sons. ${ }^{15}$

Additionally, domestic violence is a natural extension of the phenomenon of communal violence - the man who quarrels in the street or at work will inevitably use the same method in the home with his wife, and the son who resorts to violence in school or university will do so elsewhere with young women.

Furthermore, there are insufficient public policies that oppose domestic violence. Long-term educational programmes to increase awareness are missing in nearly all schools, colleges, universities and other educational institutions. National - and even international - efforts are limited to holding workshops and training programmes that have been unable to accomplish anything noteworthy. ${ }^{16}$ In addition, social protection programmes have not yet developed to the point where they can be considered to constitute all elements of the pillars of protection of battered women, according to international standards. This contributes to the growing levels of domestic violence and the lack of care for victims of domestic violence, as battered women lack legislative and institutional rules to protect them and take care of their children. Children can constitute a pressure tool for parents to make concessions and to protect the family from disintegration, as the belief predominates among large segments of the community that the use by battered women of any institution or judicial body will only escalate the conflict within the family.

\section{International Standards for Protection against Sex Discrimination and Violence of Women's Rights}

The past years have seen a growing trend in international consideration of violence against women and discrimination against them on the basis of sex. The Universal Declaration of Human Rights (1948) emphasizes the equality of all human family members for the enjoyment of their human rights, ${ }^{17}$

15 Layla Naffa et al., 'Shadow NGO report to CEDAW Committee Jordan: Evaluation of national policy measures and actual facts on violence against women', July 2007.

16 Willis C. Newman \& Esmeralda Newman, Domestic Violence: Causes and Cures and Anger Management (Tacoma, wA: Newman International, 2008), 5-8.

17 The Universal Declaration of Human Rights (UDHR) is a declaration adopted by the UNGA on 10 December 1948 at the Palais de Chaillot, Paris. It arose directly from the experience of the Second World War and represents the first global expression of rights to which all human beings are inherently entitled. For further information see Johannes Morsink, 
and both the International Covenant on Civil and Political Rights ${ }^{18}$ and the International Covenant on Economic, Social and Cultural Rights confirm the right of individuals to enjoy their rights without discrimination..$^{19}$ Jordan is a signatory to all these instruments and is therefore obliged to enforce its rules within its national legal system.

However, that international protection has been insufficient to achieve justice in the enjoyment of the rights of the family on an equal footing. Thus, international efforts have begun to pay more attention to mentioning the rights of women in public international discourse, with the United Nations General Assembly (UNGA) declaring 25 November as the International Day for the Elimination of Violence against Women, inviting governments, international organizations and non-governmental organizations (NGOs) to organize activities to raise public awareness of the problem. Several conferences have also been held to that end, the most important of which were the World Conference on Women (Mexico City, 1975), ${ }^{20}$ which discussed women's rights; the Copenhagen Conference (1980); ${ }^{21}$ the Conference of Nairobi (1985); ${ }^{22}$

The Universal Declaration of Human Rights: Origins, Drafting, and Intent (Philadelphia: University of Pennsylvania Press, 1999).

18 The International Covenant on Civil and Political Rights (ICCPR) is a multilateral treaty adopted by the UNGA on 16 December 1966 and in force from 23 March 1976. It commits its parties to respect the civil and political rights of individuals, including the right to life, freedom of religion, freedom of speech, freedom of assembly, electoral rights and rights to due process and a fair trial. For further information see Sarah Joseph \& Melissa Castan, The International Covenant on Civil and Political Rights: Cases, Materials (Oxford: Oxford University Press, 2014).

19 The International Covenant on Economic, Social and Cultural Rights (ICESCR) is a multilateral treaty adopted by the UNGA on 16 December 1966 and in force from 3 January 1976. It commits its parties to work toward the granting of economic, social, and cultural rights (ESCR) to the Non-Self-Governing and Trust Territories and individuals, including labour rights and the right to health, the right to education, and the right to an adequate standard of living. For further information see Ben Saul, David Kinley \& Jaqueline Mowbray, The International Covenant on Economic, Social and Cultural Rights: Commentary, Cases \& Materials (Oxford: Oxford University Press, 2014).

20 The Mexico City Conference was called for by the UNGA to focus international attention on the need to develop future-oriented goals, effective strategies and plans of action for the advancement of women.

21 The Copenhagen Conference called for stronger national measures to ensure women's ownership and control of property, as well as improvements in women's rights to inheritance, child custody and loss of nationality.

22 The conference aimed to evaluate the progress made during the un Decade for Women and devise a new course of action for the advancement of women. At the conference, all 
the Conference on Population and Development (Cairo, 1994);3 and the Conference of Beijing (1995). ${ }^{24}$

In 1993, the Vienna World Conference on Human Rights, acknowledging that violence against women constitutes a flagrant violation of fundamental human rights, called for a special rapporteur on violence against women to be appointed. ${ }^{25}$ Also released in 1995, the Beijing Declaration and Platform for Action put violence against women within the priority of the twelve critical areas of concern. The agreed conclusions focused on eliminating all forms of violence against women and girls, and spoke out against them. ${ }^{26}$ The UNGA's resolutions concerning the intensification of efforts to eliminate all forms of violence against women, and trafficking in women and girls, were agreed for $2012 .{ }^{27}$

Even though these conferences have issued findings and recommendations, they are not legally binding on states. However, they may have contributed to creating knowledge and to encouraging a push to activate and protect the rights of women, the most important of which is to be protected from violence. The culmination of this special international effort to eliminate domestic violence was the international community's issuing the Convention on the Elimination of All Forms of Discrimination against Women (CEDAW) in 1979, ${ }^{28}$

participants set their differences aside and awarded equal consideration to these interrelated and mutually reinforcing goals.

23 The conference was coordinated by the United Nations in Cairo, Egypt, 5-13 September 1994. Its resulting Program of Action was the steering document for the United Nations Population Fund.

24 The 1995 Fourth World Conference on Women in Beijing marked a turning point for the global agenda for gender equality. The Beijing Declaration and the Platform for Action, adopted unanimously by 189 countries, is an agenda for women's empowerment and is considered the key global policy document on gender equality.

25 The World Conference on Human Rights was held by the United Nations in Vienna, Austria, 14-25 June 1993. It was the first human rights conference held since the end of the Cold War. The main result of the conference was the Vienna Declaration and Programme of Action.

26 This Declaration and Platform for Action is an agenda for women's empowerment. It aims at accelerating the implementation of the Nairobi Forward-looking Strategies for the Advancement of Women, and at removing all the obstacles to women's active participation in all spheres of public and private life through a full and equal share in economic, social, cultural and political decision-making. It was adopted at the 16th plenary meeting, on 15 September 1995.

27 A/RES/67/144 and A/RES/67/145, of 20 December 2012.

28 CEDAW is an international treaty adopted in 1979 by the UNGA. Described as an international bill of rights for women, it was instituted on 3 September 1981 and has a similar 
which is one of the most important legal mechanisms for monitoring women's rights and states' failure to adopt the necessary measures to protect women against domestic violence. CEDAW has approved General Recommendation No. 19, which states that gender-based violence undermines, and even nullifies, women's enjoyment of their human rights and fundamental freedoms under international law or under human rights conventions, and is therefore discrimination under Article 1 of CEDAW.

Although CEDAW does not explicitly cover violence against women within its provisions, an Additional Protocol (issued in 1993) has given local institutions and individuals the right to lodge complaints against their countries for violating CEDAW's provisions. ${ }^{29}$ This Additional Protocol, which sees the right to make a complaint as being crucial to developing international means to combat all forms of discrimination against women, resulted in the addition of a special clause concerning domestic violence in the general recommendations of the CEDAW Committee on the implementation of the provisions of CEDAW. This was considered an important addition, and it has been adopted and approved in international reports.

Of the other international documents related to violence against women, the Declaration on the Elimination of Violence against Women was adopted by the UNGA on 20 December $1993 \cdot{ }^{30}$ It expanded the definition of violence against women to include 'any act of gender-based violence that results in, or is likely to result in, physical, sexual or psychological harm or suffering to women, including threats of such acts, coercion or arbitrary deprivation of liberty, whether occurring in public or in private life.' ${ }^{31}$

According to the Declaration, violence against women also includes:

format to the Convention on the Elimination of All Forms of Racial Discrimination, with regard to the scope of its substantive obligations and its international monitoring mechanisms. CEDAW is structured in six parts with thirty articles total. For further details see Marsha A. Freeman, Beate Rudolf \& Christine Chinkin, The UN Convention on the Elimination of All Forms of Discrimination against Women (Oxford: Oxford University Press, 2012).

29 The Optional Protocol is an international treaty which establishes complaint and inquiry mechanisms for CEDAw. Parties to the Protocol allow the CEDAW Committee to hear complaints from individuals or inquire into 'grave or systematic violations' CEDAW. The Protocol was adopted by the UNGA on 6 October 1999 and has been in force from 22 December 2000. For further information see S. Megan Berthold, Human Rights-Based Approaches to Clinical Social Work (New York: Springer, 2015), 85.

$30 \mathrm{~A} / \mathrm{RES} / 48 / 104,85$ th plenary meeting, 20 December 1993.

31 Declaration on the Elimination of Violence against Women 1993, Art. 1. 
(a) physical, sexual and psychological violence occurring in the family, including battering, sexual abuse of female children in the household, dowry-related violence, marital rape, female genital mutilation and other traditional practices harmful to women, non-spousal violence and violence related to exploitation;

(b) physical, sexual and psychological violence occurring within the general community, including rape, sexual abuse, sexual harassment and intimidation at work, in educational institutions and elsewhere, trafficking in women and forced prostitution;

(c) physical, sexual and psychological violence perpetrated or condoned by the State, wherever it occurs. ${ }^{32}$

The importance of this Declaration in eliminating violence against women is that it obliges member states to 'exercise due diligence in preventing acts of violence against women, investigate and in accordance with their national laws, whether these acts perpetrated by the State or by private persons. ${ }^{33}$ It is understood from this text that the existence of a national law criminalizing violence against women by family members is insufficient in itself - governments must give greater effectiveness to its functions to ensure incidents of domestic violence are effectively investigated and perpetrators punished.

Among the international efforts to eradicate domestic violence is the signing of the Convention on Preventing and Combating Violence against Women and Domestic Violence (Istanbul Convention, 2011). ${ }^{34}$ The Istanbul Convention aims at achieving equality between men and women, which is important in preventing violence against women. Also, the preamble of the Convention on the Rights of Persons with Disabilities (13 December 2006) ${ }^{35}$ recognizes that

32 Ibid., Art. 2.

33 Ibid., Art. 4(c).

34 The Istanbul Convention is the first legally binding instrument that'creates a comprehensive legal framework and approach to combat violence against women' and is focussed on preventing domestic violence, protecting victims and prosecuting accused offenders. The convention was adopted by the Council of Europe's Committee of Ministers on 7 April 2011. It opened for signature on 11 May 2011 on the occasion of the 121st Session of the Committee of Ministers in Istanbul. It entered into force following ten ratifications. For further information see Stefan Kirchner, Domestic Violence against Women and European Human Rights (New York: The Associated Press, 2015).

35 The Convention on the Rights of Persons with Disabilities is an international human rights treaty of the United Nations intended to protect the rights and dignity of persons with disabilities. Parties to the Convention are required to promote, protect and ensure the full enjoyment of human rights by persons with disabilities and ensure that they 
women and girls with disabilities are often at greater risk, both within and outside the home, of violence, injury or abuse, neglect or improper treatment, and exploitation.

And within other international efforts to reduce domestic violence, the Commission on the Status of Women (CSW) was established in 1946, as a functional commission of the Economic and Social Council, ${ }^{36}$ to prepare recommendations that ensure economic, social, civil and political rights for women. The Csw's powers were expanded in 1987 to include promoting equality and development and monitoring compliance to improve the status of women at the locally, regionally, and internationally. This is the fundamental means by which one can resort to them and provide individual and collective complaints about the violation of women's rights.

In terms of international non-treaty mechanisms, in 1997 the UNGA issued its Resolution No. 86/52 on crime and criminal justice to eliminate violence against women, offering preventive measures whereby it called on member states to:

(a) develop and implement relevant and effective public awareness, public education and school programs that prevent violence against women by promoting equality, cooperation, mutual respect and shared responsibilities between women and men;

(b) develop multidisciplinary and gender-sensitive approaches within public and private entities that participate in the elimination of violence against women, especially through partnerships between law enforcement officials and the services that are specialized in the protection of women victims of violence;

(c) set up outreach programs for offenders or persons identified as potential offenders in order to promote the peaceful resolution of conflicts, the management and control of anger and attitude modification about gender roles and relations;

enjoy full equality under the law. The text was adopted by the UNGA on 13 December 2006 and it came into force on 3 May 2008. For further information see Gudmundur Alfredsson, Jonas Grimheden \& Bertrand G. Ramcharan, International Human Rights Monitoring Mechanisms: Essays in Honour of Jakob Th. Möller (Leiden: Martinus Nijhoff, 2009), 133-136.

36 The Commission on the Status of Women ( $\mathrm{Csw})$ is the principal global intergovernmental body exclusively dedicated to the promotion of gender equality and the empowerment of women. A functional commission of the Economic and Social Council (ECOSOC), it was established by Council resolution 11(II) of 21 June 1946. 
(d) set up outreach programs and offer information to women, including victims of violence, about gender roles, the human rights of women and the social, health, legal and economic aspects of violence against women, in order to empower women to protect themselves against all forms of violence;

(e) develop and disseminate information on the different forms of violence against women and the availability of programs to deal with that problem, including programs concerning the peaceful resolution of conflicts, in a manner appropriate to the audience concerned, including in educational institutions at all levels;

(f) support initiatives of organizations seeking women's equality and non-governmental organizations to raise public awareness of the issue of violence against women and to contribute to its elimination. ${ }^{37}$

The supplement to this Resolution, Model Strategies and Concrete Measures on the Elimination of Violence against Women in the Field of Crime Prevention and Criminal Justice, included a demand that member states

... shall review and evaluate their laws and their codes in order to ensure its effectiveness in eliminating violence against women and the preparation of reports on requirements that allow this kind of violence; (b) reviewing and evaluating the criminal and civil law in the framework of the national legal system to ensure that all acts of violence against women are prohibited, and the adoption of measures in the case of non-existence. ${ }^{38}$

Special committees of the United Nations are also involved in implementing field visits to areas and regions where women suffer from systematic and widespread violations. ${ }^{39}$ These committees submit their reports to the UN secretary general about the reality of women in those areas. They may also deal with the increasing cases of discrimination and violation of women's rights in armed

37 A/RES/52/86, 2 February 1998.

38 United Nations Model Strategies and Practical Measures on the Elimination of Violence against Children in the Field of Crime Prevention and Criminal Justice, E/CN.15/2014/L.12/ Rev.1, Commission on Crime Prevention and Criminal Justice Twenty-third session Vienna, 12-16 May 2014.

39 A. Chanley, Jesse J. Chanley, Jr. \& Heather E. Campbell, 'Providing refuge: The value of domestic violence shelter services', American Review of Public Administration 31(4) (2001): 393-400. 
conflicts and wars, and suffering of women from rape and trade in human beings and other types of physical and psychological violence. Security Council Resolution Nos. 1325 and 1820 pertain to women's participation in stopping conflict processes and in making peace in conflict and post-conflict situations. ${ }^{40}$

On the judicial level, many decisions made by international and regional courts have condemned violence against women. For example, the European Court of Human Rights (ECtHR) handed down a judgment against Bulgaria for violating Article 8 of the European Convention on Human Rights (the right to respect for family life). Bulgarian authorities had failed to take the necessary measures to punish the complainant and had failed to open an investigation into the violence suffered by the complainant, arguing that it was a private issue. ${ }^{41}$ In another case, against Turkey, the ECtHR pointed out that acts of violence directed at the complainant and her mother should be considered based on sex, and then would have to be considered as discrimination against women, so the authorities should have considered this as family violence and taken appropriate measures to deal with it. ${ }^{42}$

There are many reasons why domestic violence is a serious issue in Jordan. First is the structure of the Jordanian family and the distribution of power within it. It is beyond doubt that, for traditional reasons, Jordanian society is a patriarchal one, whereby men are granted power, privilege and control over women and children. ${ }^{43}$ Men have ultimate power and exercise complete authority over all the family's affairs because they have access to material and social resources. They assume the role of financial providers and are considered to be the 'masters of the family', whereas wives take on the role of the caregiver responsible for childbearing and homemaking. Women are expected to fulfil these roles, including loyalty to their husbands and preserving the reputation of their families, otherwise they are condemned socially and may be exposed

$40 \quad$ See sc Res. 1325, 31 October 2000, \& sC Res. 1820, 19 June 2008. Also see Amy Barrow, 'UN Security Council Resolutions 1325 and 1820: Constructing gender in armed conflict and international humanitarian law', International Review of the Red Cross 92(877) (2010): 223.

41 Hristovi v. Bulgaria (Application no. 42697/05), Judgment, Strasbourg, 11 October 2011.

42 Juhnke v. Turkey (Application no. 52515/99), Judgment, Strasbourg, 13 May 2008 [Section IV].

43 See Diab al-Badayneh, National Framework for the Protection from Family Violence (Amman: National Council for Family Affairs, 2005). 
to physical punishment. An abused woman cannot request a divorce, because she will be socially ostracized and accused of being rebellious and not caring about her family and children. ${ }^{44}$ To avoid such consequences, women have to comply with social and cultural rules and should adhere to all instructions and orders given by men to avoid punishment.

In this regard, women in Jordan still widely accept that violence against them by men could sometimes be justifiable. In a study on attitudes of Jordanian women towards wife-beating, it was reported that a large percentage of women believed that the violence experienced at the hands of men was justified and beneficial. ${ }^{45}$ As a result, women do not seek help from governmental agencies.

A second reason for the high level of domestic violence in Jordan is the fact that because a man's honour is measured by his wife's devotion, women can also be seen as a source of shame and dishonour to the family. Restoring the family's honour once the wife deviates from ethical and social norms is seen as the responsibility not only of the husband, but also of the male family and tribe family and members. In this regard, Jordanian laws encourage domestic violence - multiple provisions in the Jordanian Penal Code reduce penalties in 'honour' crime cases. Article 340, for example, gives extenuating excuses for crimes of 'honour'. Any man who kills or attacks his wife or any of his female relatives while they are in the act of committing adultery or in an 'unlawful bed' benefits from a reduction in penalty. ${ }^{46}$

Another provision in the Penal Code, frequently invoked on behalf of perpetrators of 'honour' killings, is Article 98, which mandates a reduction of penalty for a perpetrator (of either gender) who commits a crime in a 'state of

44 Diab al-Badayneh, National Security in the Globalization Age (Amman, Ministry of Culture, 2009).

45 Muhammad Haj-Yahia, 'Violence against women and battering in the sociocultural context of Arab society', Family Process 39(2) (2000): 237-255.

46 Article 340 of the Jordanian Penal Code provides ' 1 . There shall benefit from the mitigating excuse (uthur mukhafif) whosoever surprises his wife or one of his ascendants or descendents in the crime of adultery or in an unlawful bed, and kills her immediately or kills the person fornicating with her or kills both of them or attacks her or both of them in an assault that leads to death or wounding or injury or permanent disability. 2. Shall benefit from the same excuse the wife who surprises her husband in the crime of adultery or in an unlawful bed in the marital home and kills him immediately or kills the woman with whom he is fornicating or kills both of them or attacks him or both of them in an assault that leads to death or wounding or injury or permanent disability. 3. The right of lawful defence shall not be permitted in regard to the person who benefits from this excuse nor shall the provisions of "aggravated circumstances" (thuruf mushaddida) apply'. 
great fury (or "fit of fury") resulting from an unlawful and dangerous act on the part of the victim. ${ }^{47}$ It does not require in flagrante discovery or any other standard of evidence of female indiscretion. If the extenuating excuse is established for a crime punishable by death, such as premeditated murder, the penalty is reduced to a minimum of one year in prison. ${ }^{48}$ For other felonies, it can be reduced to a minimum of six months and a maximum of two years.

For Article 98 to be applied, it is not necessary for the murder to have been provoked by any actual proof of sexual indiscretion. In practice, the mere suspicion of a woman's unlawful and dangerous act, often simply called a 'bad act', may be sufficient proof for the courts to reduce penalties. ${ }^{49}$ Article 98 was applied, for example, in a 2001 case in which the defendant had killed his sister 'after seeing a man leave her house'. ${ }^{50}$ It was also applied in the 2002 case of a man who had killed his sister after seeing her 'talking to a strange man during a wedding party'.51 In 2003, a man fatally stabbed his daughter twenty-five times because she refused to tell him where she had been, following a three-week absence, and the court, invoking Article 98, reduced his sentence on the basis of the act having been committed in a 'fit of rage. 52

Court precedents indicate that reacting violently to perceived stains on family honour will generally be found to have occurred in a 'fit of fury', even where substantial time passes between knowledge of the alleged 'bad act' and the commission of the crime. In a reported case, a man, hearing his sister referred to as a 'slut', confronted her. She told him to 'mind his own business'. He strangled her the following morning with a phone cord. The High Criminal Court ruled that:

It does not matter that the defendant killed his sister hours after [learning of her supposed act]. He was still under the influence of extreme

47 Article 98 of the Penal Code reads as follows: 'Anyone who commits a crime in a state of great fury resulting from an unlawful and dangerous act on the part of the victim shall benefit from the extenuating excuse'.

48 Honour Crimes under Jordanian Law, www.hrw.org/reports/2004/jordano404/4.htm\#_ ftn51.

49 Human Rights Watch, 'Honoring the killers', Human Rights Watch 16(1) (April 2004): 19.

50 Rana Husseini, 'Court tribunals invoke Article 98 to set three murderers free', Jordan Times, 2 April 2001.

51 Rana Husseini, 'Killers receives a reduced sentence following cassation order', Jordan Times, 23 September 2002.

$5^{2}$ Rana Husseini, 'Father given 6 months for stabbing daughter 25 times', Jordan Times, 1 January 2003 . 
anger, which caused him to lose his ability to think clearly because of the unlawful act committed by his sister. ${ }^{53}$

In a 2001 case, a brother had visited his sister in a hospital where she was being treated for burns, and she admitted to him that she had had an affair and was pregnant. He left and bought a gun, returning twenty-four hours later when he shot her seven times at close range. As the court saw it:

although there were approximately twenty-four hours between the time the defendant learnt of his sister's illegitimate pregnancy [and the time he killed her], his soul was not at peace ... The irritated soul does not know calm thinking. Therefore, he should benefit from a reduction in penalty as stipulated in Article 98 of the Jordanian Penal Code. ${ }^{54}$

Article 99 of the Penal Code also has a negative impact on honour crimes in Jordan. It allows criminal courts to halve the sentence if the victim's family waives its right to file a complaint, which, given its complicity in 'honour' crimes, the family nearly always does. Thus, 'honour' killers may receive sentences of six months - and often do. ${ }^{55}$ If a killer has served that much time awaiting trial, the sentence may be commuted to time served, and he may walk away a free man. In a 2003 case, a thirty-year-old man who had murdered his divorced sister for being absent from the family home for one week, was sentenced to six months for the 'honour crime' due to the mitigation granted under Article 98, and was set free having served the time while awaiting trial, after the father of the victim, who was also the father of the defendant, dropped charges. ${ }^{56}$

The only official effort to protect women threatened by their families for perceived violations of family honour has been to place them into the protective custody of prisons or correctional facilities. Officially, such women are referred to as 'administrative detainees'. ${ }^{57} \mathrm{~A}$ woman victim is thus imprisoned so that she will not be killed by relatives for having 'dishonoured' the family,

53 Rana Husseini, 'A man gets one year for killing sister', Jordan Times, 1 June 2003.

54 Rana Husseini, 'Court tribunals invoke Article 98 to set three murderers free', Jordan Times, 2 April 2001.

55 See 'Thirty-year old man receives six months for killing sister', Jordan Times, 20 January 2003 .

56 See Case No. 1037/2003 before the Criminal Court of Cassation.

57 Rana Husseini, 'Government urged to release, protect women threatened by relatives', Jordan Times, 17 December 1998. 
while her attacker goes free. Reportedly, official statistics indicate that fifty to sixty women threatened by their families on the basis of honour are placed every year in administrative detention, for periods ranging from a few months to more than three years. ${ }^{58}$

\section{Protection Standards against Domestic Violence against Women in Jordanian Law}

Jordan has engaged in the global movement to combat violence against women, ratifying relevant international conventions and participating in all activities considered necessary to eliminate violence against women. It has also enacted national legislation and adopted policies, plans and strategies and other means within the framework to restrict and prevent the spread of domestic violence. In 2011, it added two new paragraphs to Article 6 of its Constitution. ${ }^{59}$ The first states that 'The family is the basis of society the core of which shall be religion, morals and patriotism; the law shall preserve its legitimate entity and strengthen its ties and values'. The second states that 'The law shall protect motherhood, childhood and the old-aged; and shall avail care for the youngsters and those with disabilities and protect them against abuse and exploitation'. The Jordanian Constitution, in the first paragraph of Article 6 , also guarantees the principle of equality between Jordanians, who are equal before the law without any discrimination between them.

Prior to that, Jordan issued the Law Regarding Protection from Domestic Violence (Law No. 6/2008) and ratified CEDAW in 2007. Jordan also continues to provide periodic reports to the CEDAW Committee. In 2012, it presented its fifth periodic report, which pointed to the progress made by the Jordanian state in protecting women from domestic violence, achieving equality between the sexes and improving the status of women. ${ }^{60}$

In turn, the CEDAW Committee submitted its recommendations to the Jordanian report. These recommendations included that the Jordanian government address the rights of women in various areas, including the adoption

$5^{8}$ See 'Contents of Article 340 of the Penal Code regarding honour killings', www.ecoi.net/ local_link/183325/300726_de.html.

59 For the 2011 amendments to the Constitution, see the Official Gazette No. 5117, 1 October 2011, 4452.

6o See Jordan's Fifth National Periodic Report to the CEDAW Committee, prepared by the Jordanian National Commission for Women in 2010, www.women.jo/admin/document/ CEDAW\%2oEnglish.pdf. 
of comprehensive laws that achieve gender equality. The Committee also recommended that Jordan introduce statutory measures to address all forms of violence against women and girls, including rape; create special shelters for women in urban and rural areas; and strengthen measures to increase the representation of women in public life, especially in leadership positions. The Committee called for Jordan to review its reservations to the Convention, to ratify the Optional Protocol attached to the Convention, and to amend the labour law in a way that prevents sexual harassment and discrimination and reduces the incidence of early marriage. ${ }^{61}$

At the national level, on 20 January 2013 the Council of Ministers approved the National Strategy for Jordanian Women for the years 2013-2017. The Strategy was prepared by the Jordanian National Committee for Women's Affairs in collaboration with all stakeholders in women's rights. It is aimed at strengthening women's role in policymaking and decision-making in the various themes and sectors that qualify for public participation in family, community and nationbuilding, and sustainable development in society with justice, equality and equal opportunities. It also focused on empowering women politically and economically, and protecting them from violence. ${ }^{62}$

However, despite of all of the above, figures indicate that violence against women is still routinely practiced in Jordanian society, as shown in the reports issued by the national institutions for protection against domestic violence.

\section{National Institutions for Protection against Domestic Violence}

\subsection{National Council for Family Affairs}

Many Jordanian institutions and national bodies are concerned with protecting women against violence, foremost of which is the National Council for Family Affairs (NCFA). The NCFA was founded under the Law of the National Council for Family Affairs (Law No. 27/2001). ${ }^{63}$ An umbrella organization, it coordinates and facilitates work between partners from governmental and non-governmental organizations, international institutions, national institutions, and the private sector working in the area of family, and helps them to work together to achieve the best for the families of Jordan's future. ${ }^{64}$ It also

$61 \mathrm{CEDAW} / \mathrm{C} / \mathrm{JOR} / 5,24$ September 2010.

62 Dr. Muna Mou'tamen, 'The national strategy for Jordanian women for the years 2013-2017', Alrai, 7 March 2013.

63 See the Official Gazette No. 4496, 16 July 2001, 2778.

64 Law No. 27/2001, Art. 6. 
seeks to strengthen the role of the Jordanian family in society to ensure a better standard of living, through a national vision that supports the country's development policies. ${ }^{65}$

In order to achieve its strategic objectives, the NCFA is working on a national policy, legislation and procedures relating to the review and modification of family preparation, and will guide scientific research and programmes related to the family in Jordan and the promotion of national priorities.

One of the other tasks carried out by the NCFA is managing all information related to families in Jordan and submitting it to the relevant authorities in order for well-thought-out decisions to be made, to ensure the continuity of progress and greatness of the family of Jordan on scientific grounds. The NCFA also mobilizes national support for policies and programmes to promote the family and the rights of family members, thus ensuring the establishment of a broad base of decision-makers who have the knowledge and expertise on the most important family issues. It also works to provide financial support to ensure the continuity of family programmes, and on the sustainability of coordination and follow-up applications and implementation of policies and strategies related to the family. ${ }^{66}$

\subsection{Family Protection Department}

Another body related to protection of the family is the Family Protection Department against Violence (FPD), created by the Public Security Directorate (PSD) in 1997 to deal with reported cases of domestic violence and assault. The FPD's establishment was the embodiment of the Royal vision of the need to pay adequate attention to childhood and women, and provide better services to them. It is also to promote the humanitarian and social roles of the PSD in the follow-up and treatment of domestic violence and sexual assault cases. In addition, there is also the need to change interrogation techniques and interviews with victims of these issues. and motivate them to go to the relevant bodies with their complaints. Finally, it is to form this distinct Jordanian administration model in participatory work between the PSD and a number of relevant government and non-governmental institutions. ${ }^{67}$

\footnotetext{
65 Ibid.

66 Ibid.

67 National Council for Family Affairs, The Reality of Violence against Women in Jordan (Amman: USAID, 2008), 24.
} 


\subsection{Jordanian National Commission for Women}

The Jordanian National Commission for Women (JNCW), established (following a decision of the Council of Ministers in 1992) to raise public awareness of the importance of women's role and to consolidate their position in the progress of Jordanian society, works as an observatory organisation. It conducts a national analysis of the mechanisms that operate in the field of women and the pursuit of documented and institutionalized violence. It monitors the status of women and their needs in accordance with national and international developments, and works on the application of international conventions and treaties ratified by the Jordanian government regarding women's rights. This helps to ensure transparency in their application, and the development of systems and effective procedures to measure the extent of what has been implemented by national institutions in the context of achieving the objectives of the strategies, policies, plans, programmes and projects concerned with the advancement of women. ${ }^{68}$

In 1993 the JNCW developed the first national strategy for women. It has also organized many women's studies to identify areas of concern and priorities for action. All of the official authorities consider it the main reference for women's affairs. It was assigned to officially represent Jordan at the Fourth World Conference on Women in Beijing in 1995.

\subsection{The Ministry of Social Development}

The Ministry of Social Development (MSD) helps to develop and implement social policy; promotes cooperation between the public and private sectors to maximize the utilization of available resources; and organizes social work and civil volunteers, and activates the provision of social services. The MSD also aims to achieve community justice through advancing social work and developing comprehensive and social policies, improving the quality of life of its members, and employing information and knowledge to provide excellent social services, as well as consolidating sustainable development based on the principles of accountability and a participative process. ${ }^{69}$ To these ends, the Ministry of Social Affairs Law (No. 14/1956) was issued, ${ }^{70}$ which stipulates that the ministry shall provide comprehensive social security, competence and productivity, and coordinate social services for all citizens in all stages of

\footnotetext{
68 Ibid., 25-26.

69 Law No. 14/1956, Art. 3.

$70 \quad$ See the Official Gazette No. 1265, 16 March 1956, 1367.
} 
life, as well as the organization of their investment in the production of state resources. ${ }^{71}$

\subsection{National Centre for Human Rights}

Finally, the National Centre for Human Rights (NCHR), which grew in independent public interest as a national institution under Law No. 51/2006, has financial and administrative independence in the exercise of all intellectual and political activities and events related to human rights. ${ }^{72}$ The NCHR promotes the principles of human rights in Jordan, inspired by the tolerant message of Islam, by Jordan's Arab and Islamic heritage and values, and by the Constitution of rights, as confirmed by international charters and conventions of principles. ${ }^{73}$ It also contributes to the consolidation of human rights principles in Jordan, both in terms of thought and practice; promotes non-discrimination between citizens on grounds of race, language, religion and sex; and promotes a democratic approach, being a model for integration and balance based on a climate of freedom, ensuring political pluralism and respect for the rule of law, while guaranteeing the right to economic, social and cultural development, and the pursuit of Jordan's accession to international conventions and agreements on human rights in general and women's rights in particular. ${ }^{74}$

\section{The Jordanian Law for Protection against Domestic Violence}

The Law Regarding Protection from Domestic Violence (Law No. 6/2008) was passed to maintain family ties and reduce the effects of penal procedures against crimes committed by family members. It allows the director of the Family Protection Department (FPD) to take precautionary protection measures, the most important of which is to bar the defendant from the family home for up to forty-eight hours if there is no other way to ensure the protection of the victim or a family member. ${ }^{75}$ The law also gives those in charge the right to keep the defendant for up to twenty-four hours in the FPD or one of its divisions, while ensuring protection of the victim or any of the family members if none of the previous procedures can be adopted. ${ }^{76}$

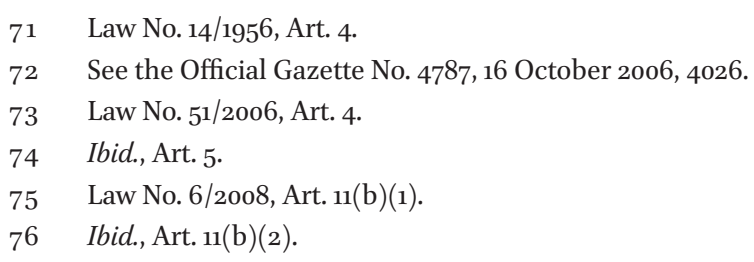


Under the law, Committees of Family Reconciliation have been developed. These committees will attempt to reconcile family members. ${ }^{77}$ The law also requires all providers of health, social and educational services from the private and public sectors to inform the competent authorities if they notice any signs of violence. It also enjoins staff to take steps to enforce measures affected, and protect the person in question from domestic violence. They are asked not to name or identify the subject to legal liability except in the event of judicial proceedings. ${ }^{78}$ In the absence of an agreement between the parties, the case should be referred to the court. If at any time the parties settle the dispute, the prosecution of the defendant can be stopped..$^{79}$

The law also gives the court the right to issue a protection order for up to one month, requiring the defendant not to bother the victim or any of the family. ${ }^{80}$ The order would also prevent the defendant from approaching a place of alternative accommodation, whether this is a safe place, nursing home or any other place mentioned in the protection order. The order can be renewed for six months in case of a violation by the defendant, or if the court is satisfied of the need to provide greater protection to the victim or any family member. ${ }^{81}$

However, the Jordanian law also includes many obstacles to preventing, deterring and eliminating domestic violence. Most important, it lacks any definition of domestic violence. Legislators have thus begun to revise procedural provisions and objectivity about protection against domestic violence without putting in place a prohibitive and inclusive definition of what constitutes domestic violence, in the light of the application of penal provisions in the law.

The Jordanian law also fails to address the issue of violence outside the family home. In order to be considered domestic violence, an act or acts (or threats of such) must originate from a person who lives with family members in the same family home. 'Family members' are defined as any of the following who reside in the family home: husband and wife under a legal marriage, and their children and grandchildren, and finally the children of a couple of a legal marriage, the father and mother of either spouse, brothers and sisters of either spouse, or persons covered by the custody of foster parents who are not yet eighteen years of age..$^{82}$ This approach would narrow the scope of domestic violence and limit it to violence against family members inside the family

\footnotetext{
77 Ibid., Art. 6.

78 Ibid., Art. 10.

79 Ibid., Art. 12(b).

$80 \quad$ Ibid., Art. 14(a).

81 Ibid., Art. 14(b).

82 Ibid., Arts. 2 and 3.
} 
home. Any violence practiced outside the family home would be out of the framework of the law.

The law does not address violence practiced against women or family member of someone who does not reside with them in the same home. If women are subject to violence by persons mentioned in the law outside the family home, or exposed to violence from those mentioned in the law within the family home, such acts are not covered by the provisions of the law.

Furthermore, the Jordanian law ensures a departure from the general rules in the Code of Criminal Procedure governing the powers of the judicial police and their competence, where the law permits the director of the FPD to depart from the general rules and take quasi-judicial proceedings to close the complaint file and not to refer the matter to the competent court, or to prevent the defendant from entering the family home for as much as twenty-four hours. These powers must not be exercised by any non-judicial person or vested in any non-judicial point because they directly prejudice the rights of individuals, even including the aggressor, on the grounds that the accused is innocent until proven guilty of a judicially defined offence. These powers must therefore be exercised under the supervision and control of judicial powers.

In the area of regulation of the process of prosecution, the law stipulates the referral of the complaint to the Family Reconciliation Committees with the consent of all parties and that, in the case of disapproval, the complaint can be turned over to the competent court. It is better to refer every case of domestic violence sentenced to the Family Reconciliation Committee without requiring the consent of the parties as a first stage before they are forwarded to the competent court. For cases of repeated violence and complaint against the defendant to be excluded, the case should be referred directly to the competent court.

Legal sanctions for a defendant's not complying order precautionary protection - non-deterrent penalties are limited to imprisonment for not more than one week, and if the defendant violates a protection order, the sentence is deliberately limited to a fine of one hundred dinars, or imprisonment for a period not exceeding one month. Even if a defendant repeatedly violates a protection order, the penalty is only imprisonment ranging from three days to six months, and a fine not exceeding two hundred dinars. This also is a deterrent sanction.

The law on compensation to the victim may have been prompted by restrictions and controls to limit its value; the most important thing is the financial situation of the parties to the conflict and the impact of forcing the defendant to pay full compensation to the family situation, and expenses incurred as a result of protective measures. These factors are not related to the victim, so 
should not be taken into account when assessing any compensation to him for domestic violence.

\section{Conclusions and Recommendations}

The fight against violence against women will likely not achieve tangible results in the short-term, given the characteristics of the crime and the impunity enjoyed by the perpetrators of violence. Gender-based violence is accepted and justified by Jordanian society as a form of male dominance over women, making it difficult to eliminate it - in some cases, violence against women is a crucial social mechanism that subordinates women to men.

The issue of impunity in cases of violence against women has been of paramount importance in the work of international and regional organizations. These organizations stress that the state must fight against violence and take administrative, executive, judicial and legislative measures to eliminate violence against women. The framework of the international campaign launched by the secretary general of the United Nations to eliminate violence against women and to put an end to impunity has been demanded of all countries, including Jordan, as has the development of a national strategy and action plan in partnership with all the actors to be enforceable in application and measurement, to eliminate violence against women.

Jordan has been invited to assess the phenomenon of domestic violence on an objective and scientific basis. This can be accomplished by building on positive teamwork in a national context of collective, (and not individual) founders, as was formerly the case. It will help to put an end to the growing phenomenon of domestic violence, before beginning to think about finding mechanisms and solutions to eliminate the phenomenon. All of this should all be done through the development of national legislation and public policies primarily aimed to combat violence against women.

Although the Law Regarding Protection from Domestic Violence (Law No. 6/2008) has a number of positive provisions, it is marred by a number of negative points. Among the most important of these is that a definition of domestic violence has been overlooked. Another allows the judicial police of the FPD to take quasi-judicial decisions and actions, which need specialist judicial supervision. In addition, it requires conflicting parties to consent before their dispute can be referred to a Committee of Family Reconciliation. Priority should be given to reconciliation and consensus in the prosecution of the defendant, which raises doubts about the possibility of dropping the punishment. The 
prescribed sanctions are ineffective in public and private deterrence, and the law violates the aggrieved party's right to compensation. In conclusion, the following set of recommendations and suggestions are presented to be included in any review of the Law No. 6/2008:

(1) Amend the law to ensure the activation of the content and spirit of the constitutional provisions that guarantee non-discrimination between Jordanians, family welfare and young people, and in accordance with the general principles of international standards of human rights in general and women in particular, and include a definition. It should also manage to keep domestic violence under scrutiny and keep its provisions objective, most important of which is to oblige the Judicial Police and public security officers to go to the actual place of the occurrence of domestic violence. In this context, it can be guided by the definition of domestic violence contained in the Declaration on the Elimination of Violence against Women adopted by the UNGA on 20 December 1993 .

(2) Expand the scope of application of the law to include all aspects and forms of violence exercised by the designated members of the family-in-law towards each other, whether this violence occurs inside the family home or outside it, such as at a place of work, or in the house of any other family member. Ensure rapid and secret investigation of the offence of domestic violence. Identify specific tasks and functions of the institutions designated to prosecute this offence, and do not to expand the granting of discretionary powers in the event of a crime or to give priority to reconciliation or other forms of mediation.

(3) Find more effective ways to ensure the protection of the rights of victims of domestic violence, to protect witnesses and whistleblowers from reprisals and violence, and to punish all partners or those intervening in acts of domestic violence. Any exceptions from punishment or downgrading of punishment, should also be abolished, and penalties must be increased in case of repeated domestic violence.

(4) Provide battered women with shelters, financial assistance and services. Train policewomen to deal with victims of domestic violence. Think seriously about the establishment of family courts with special measures to protect the victims and their children, taking into account the best interests of the children involved. 
(5) Include legislative provisions to ensure continuous and accurate disclosure of numbers and statistics related to crimes of domestic violence for use in research studies, which are to address this phenomenon and limit its spread. Include preventive measures against domestic violence, including to change stereotypes and the relevant social and cultural image, and any other ideas that are based on discrimination against women or are inconsistent with fundamental rights. The law should not include any contraindications concerning punishment or accountability based on customs, traditions, social considerations or family.

(6) Adopt a national strategy to ensure the law is implemented and to identify clearly each of the institutions and relevant bodies' roles concerning crimes of domestic violence, including committees of family harmony, thus reducing the turmoil that the institutions concerned may suffer. The multiplicity of agencies that work to limit this crime will have a negative impact in the fight if there is no coordination of work between them. It should activate the role of civil society and involvement in the fight against domestic violence, and provide support for victims of domestic violence through all the trial proceedings and beyond, ensuring that the contribution of the media does not entrench stereotypes, but rather combats them, and strive to consolidate the values and the human rights system, and the rejection of violence against women. 